\title{
WAŻNOŚĆ ETYKI NORMATYWNEJ DLA KSZTAŁTOWANIA KULTURY MORALNEJ MEODEGO POKOLENIA. REFLEKSJA W ŚWIETLE NAUCZANIA KAROLA WOJTYŁY - ŚW. JANA PAWŁA II I JEGO UCZNIÓW
}

Streszczenie: Jan Paweł II przypomniał w siedzibie UNESCO w Paryżu dnia 2 czerwca 1980 roku, że kultura moralna jest pierwszym i podstawowym wymiarem każdej autentycznej kultury będącej „właściwym kształtem życia człowieka jako takiego”. Młody człowiek powinien nabywać kulturę moralną m.in. na drodze edukacji, tzn. kształcenia i wychowania. Ważnym elementem w tej pracy jest etyczny namysł nad życiem i działaniem człowieka. Jednak nie każda etyka (model etyczny, kierunek etyczny) służy wspomnianemu procesowi. Proponowany artykuł prezentuje główne idee etyki normatywnej w odniesieniu do kultury moralnej w myśli filozoficzno-teologicznej Karola Wojtyły - św. Jana Pawła II.

Słowa kluczowe: etyka normatywna, kultura moralna, moralność, prawda, dobro i zło moralne, sumienie.

\section{Wstęp}

Czasy, w których żyjemy, charakteryzują się zasadniczym sporem o moralność i jej sens w życiu współczesnego człowieka, a pośrednio o kształt pożądanej etyki ${ }^{1}$. Sytuacja ta generuje subiektywizm i relatywizm moralny, powodując zagubienie i kryzys osoby - szczególnie młodej, szukającej swojej specyfiki i miejsca w świecie. Poza tym żyjemy w czasach wszechpanującej liberalnej ekonomii, której zasady

${ }^{1}$ Etyka tak ma się do moralności, jak teoria do praktyki. Niewątpliwie rozumienie moralności zależy od lansowanej etyki i vice versa. Bardzo interesujące są sprzęgnięte relacje między etyką i moralnością, o czym dość często zapominają pedagodzy, tworząc konkretną koncepcję wychowania moralnego. Do etyki dochodzimy przez moralność, tzn. przedrefleksyjna praxis moralna poprzedza etykę jako twór racjonalny, prowadząc także do poszukiwania wartości absolutnej dostarczającej wyjaśniające racje dla przeświadczeń moralnych. Z kolei człowiek, aby uniknąć błędów moralnych, m.in. poprzez poddanie fenomenu sumienia i jego treści dialogowi z innymi sumieniami, powinien czynić to za pośrednictwem adekwatnej etyki (Wiśniewski 2016). 
(m.in. rywalizacja i maksymalizacji zysku - tzw. logika rynku) przenoszone są na relacje międzyludzkie, co prowadzi m.in. do utylitarystycznego traktowania drugiej osoby. Dlatego współczesne społeczeństwa potrzebują kultury moralnej ${ }^{2}$, która kształtowałaby autentyczne relacje osoby odnośnie samej siebie i innych ludzi, a także rzeczywistości ją otaczającej (Rodziński 2011). Aby jednak adekwatnie podjąć to dzieło, potrzeba na początku odpowiedzieć na zasadnicze pytania: czym jest moralność?; czy człowiek jest z natury bytem moralnym?; czy można poznać moralność w sposób racjonalny?; jakie są źródła ludzkich ocen i norm moralnych?; co to jest dobro moralne?; jaka etyka jest w stanie adekwatnie opisać i prezentować autentyczną moralność?

Prezentowany artykuł podejmuje się odpowiedzi na powyższe pytania i wskazuje zarazem na etykę normatywną, która w ujęciu Karola Wojtyły - Jana Pawła II i jego uczniów ${ }^{3}$ stała się etyką normatywnej mocy prawdy, będącą na poziomie opisu etycznym personalizmem (Styczeń 2016; Krajewski 2011; 2016). Aby rozwiązać zasygnalizowany już w tytule artykułu problem główny i związane z nim problemy szczegółowe, na początku zostanie zaprezentowana istota sporu o moralność i etykę. Następnie zostanie poddane analizie doświadczenie etyczne, które jest źródłem budowania etyki normatywnej. Analiza ta pomoże uchwycić kluczowe elementy i strukturę doświadczenia etycznego, a dzięki temu zrozumieć istotę moralności. W dalszej kolejności zostanie ukazana specyfika i oryginalność etyki normatywnej mocy prawdy, proponowanej dla kształtowania kultury moralnej współczesnego człowieka.

2 Zdaniem Jana Paweł II kultura moralna jest „pierwszym i podstawowym wymiarem kultury” (Jan Paweł II 1998) i fundamentem życia osobowego, i społecznego.

3 Karol Wojtyła zajmował się problematyką etyczną, pracując na Wydziale Filozofii KUL-u w latach 1958-1978. Wraz ze swoimi uczniami, ks. Tadeuszem Styczniem i ks. Andrzejem Szostkiem, stworzył lubelską szkołę etyki, a z nią specyficzny sposób rozumienia i uprawiania tej dziedziny nauki, przekraczający ramy KUL-u. Przywołana szkoła wyrosła z twórczego i krytycznego dialogu z innymi wielkimi koncepcjami filozoficzno-etycznymi, ukazując i uzasadniając etykę jako naukę normatywną. Dzisiaj myśl tej szkoły rozwijają uczniowie wspomnianych profesorów, m.in. Kazimierz Krajewski, do którego najczęściej odwołuję się w swoich analizach z trzech powodów. Po pierwsze, dokonuje on systematycznej analizy i syntezy myśli wspomnianych etyków. Po drugie, w sposób twórczy rozwija ich myśl, zachęcając tym samym innych autorów działających w orbicie refleksji tej szkoły do współmyślenia. Po trzecie, odwołując się w większości do tego autora, nie mnożę przypisów i bibliografii, aby sprawiać wrażenie erudycji, ufając, że zainteresowany czytelnik docierając do publikacji tego autora, za jego pośrednictwem, dotrze także do źródłowej literatury (Krajewski 2006; 2016). 


\section{Istota sporu o moralność i etykę}

W centrum sporu o moralność i etykę znajduje się problem epistemologicznych podstaw moralnych przekonań oraz źródeł ocen i norm moralnych, a także zagadnienie rozumienia dobra moralnego - jego natury ${ }^{4}$.

Spory o racjonalność poznania moralnego dobra i jego naturę toczą się między kognitywistami i akognitywistami (Krajewski 2011, s. 339-346). Kognitywiści (łac. cognitio - „poznanie”) twierdzą, że istnieją obiektywne podstawy ocen i norm moralnych, które można ująć w aktach poznawczych. Z tego wynika, że przekonania moralne są racjonalizowane, ponieważ opierają się na obiektywnych i poznawalnych dobrach. Kognitywizm występuje w dwóch odmianach: 1) intuicjonizm według którego wartości (dobra) są poznawalne wprost, bezpośrednio, intuicyjnie; 2) dyskursywizm - według tego stanowiska wartości są poznawalne za pomocą złożonej operacji myślowej - rozumowania (dyskursu) ${ }^{5}$.

Wewnątrz kognitywizmu toczy się także spór pomiędzy naturalizmem a antynaturalizmem. Oba stanowiska uznają, że dobro istnieje obiektywnie i podmiot jest zdolny do poznania prawdy o nim, lecz różnią się co do statusu dobra oraz sposobu jego poznania. Naturalizm uznaje, że dobro ma charakter zmysłowy, ponieważ po pierwsze, jest cechą przedmiotu, po drugie, jest cechą empiryczną, czyli naturalną. Dobro jest więc własnością tego samego typu co barwa, ciężar, smak czy kształt i jest poznawalne zmysłowo. Fakt moralny to przeżycie o charakterze zmysłowym. Faktami moralnymi są przede wszystkim przeżycia przyjemności i przykrości, pożytku oraz korzyści. Poznawalność (racjonalność) dziedziny moralności polega na jej empiryczności, czyli zdolności ujęcia w kategoriach zmysłowych. Sądy etyczne o wartościach i powinnościach są racjonalne, ponieważ są rezultatem ujęcia empirycznej rzeczywistości. Według naturalistów etyka dąży do opisania i wyjaśnienia faktu naturalnego dążenia do przyjemności (naturalizm sensualistyczny) oraz szczęścia wpisanego w ludzką naturę (naturalizm metafizyczny), bądź korzyści poszczególnych ludzi oraz grup społecznych. Naturalizm redukuje więc fakt moralny do dziedziny dążeń, czego konsekwencją jest „likwidacja” specyfiki faktu moralnego oraz odrzucenie doświadczenia etycznego (Krajewski 20o6, s. 145-147). Z kolei według antynaturalizmu dobro jest własnością swoistą, cechą sui generis, nieredukowalną do cech empirycznych, czyli własnością nienaturalną, ujmowaną za pomocą pozaempirycznej intuicji.

Wracając do pierwszego sporu między kognitywistami a akognitywistami, należy zauważyć, że ci ostatni zaprzeczają racjonalności moralności (ocen i norm moralnych), twierdząc, że ma ona charakter pozapoznawczy. Dobro (wartości)

${ }^{4}$ W tym sporze zamiennie używa się pojęć dobro i wartość, co ma odzwierciedlenie także w tej części artykułu.

5 Przedstawicielami kognitywizmu są etycy tomistyczni, personaliści, fenomenologowie, kantyści i utylitaryści (Krajewski 2011, s. 341). 
nie jest przedmiotem poznania, a przeżycie wartości nie jest przeżyciem poznawczym. Wartości, które pojawiają się w ludzkim świecie, są rezultatem ekspresji, wyrażania własnej postawy emocjonalnej, narzucania ocen bądź wartościowania ${ }^{6}$. Wewnątrz akognitywizmu wyróżnia się dwa stanowiska: 1) emotywizm - który twierdzi, że wartość jest wytworem sfery emocjonalno-wolitywnej człowieka, a zdania oceniająco-normatywne nie podlegają kwalifikacji prawdy, ponieważ nie mają charakteru logicznego. Oceny i normy moralne wyrażają jedynie emocje podmiotu wydającego ocenę, przez co mają charakter irracjonalny, emocjonalno-wokatywny ; 2) projekcjonizm - według którego wartość jest czymś wytworzonym i narzuconym („twórczość aksjologiczna”)

Obecnie, wyprzedzając niejako tok prowadzonych w tym artykule analiz i refleksji, zostanie zaprezentowane ustosunkowanie się etyki normatywnej mocy prawdy (personalizmu etycznego) do poruszanych spornych kwestii, aby następnie móc przeanalizować już kluczowe elementy tejże etyki i rozumienie w jej świetle moralności.

Personalizm etyczny wskazując na normatywny charakter doświadczenia ludzkiej osoby i moralny wymiar jej bytowania i działania, który jest warunkiem pełnego zrozumienia człowieka jako osoby, przyznaje rację kognitywistom broniącym zdolności człowieka do poznania prawdy o wartości (dobru) jako obiektywnych i zastanych przez podmiot poznający istnościach - transempirycznych kategoriach, takich jak: istnienie, byt, prawda, dobro, piękno. Personalizm etyczny stoi na stanowisku bezpośredniego poznania prawdy o dobru moralnym (godność osobowa) i prawdy o powinności jej respektowania. Zwraca również uwagę na to, że akognitywizm zamienia argumentację na perswazję, przekreślając tym samym możliwość zaistnienia etyki normatywnej. Dlatego w ramach akognitywizmu jest miejsce tylko na metaetykę, badającą językową ekspresję wyrażeń wartościujących oraz na etologię, rozumianą jako socjologia moralności i badającą społeczną genezę ocen i norm moralnych (Krajewski 2011, s. 344). Personalizm etyczny nie zgadza się także ze stanowiskiem naturalizmu, który za jedyne wartościowe poznanie uznaje

${ }^{6}$ U podstaw rozumowania akognitywizmu znajdują się założenia aprioryczne, skreślające pewne fakty z zakresu tego, co jest dane. Takim założeniem jest 1) sensualizm - uznaje on, że jedynie wartościowym poznaniem jest poznanie zmysłowe, wykluczając tym samym możliwość doświadczania rzeczywistości innej niż dane wrażeniowe. Cognosco zostaje zamienione na cogito - to, co podmiot poznaje, jest nie tyle odpoznane, co pomyślane, skonstruowane; 2) decyzjonizm - redukuje czynnik intelektualny na rzecz niczym nie skrępowanej woli (Krajewski 2006, s. 143-145).

7 W literaturze przedmiotu wskazuje się na dwa typy emotywizmu: 1) emocjonalizm akognitywistyczny (Ch. Stevenson, A. Ayera) oraz 2) emocjonalizm kognitywistyczny, przypisujący uczuciom funkcję poznawczą, reprezentowany przez fenomenologów, w szczególności przez M. Schelera (Krajewski 2010, s. 429-435).

8 Przedstawicielami emotywizmu są etycy anglosascy, natomiast projekcjonizmu - etycy i teologowie moraliści reprezentujący idee tzw. kreatywnego rozumu (Krajewski 2011, s. 342). 
poznanie zmysłowe, przez co samej moralności przypisuje charakter zmysłowy. Analizowana koncepcja etyki uważa jednocześnie, że w procesie poznawania moralności (wartości moralnych) należy kierować się integralnym i rozumiejącym doświadczeniem, co oznacza, że nie można ograniczać go tylko do doświadczenia zmysłowego, polegającego na doznawaniu treści wrażeniowych, jak tego chcą naturaliści i akognitywiści. Wartość moralna jest czymś doświadczanym, empirycznym w szerokim sensie - jest „jakością postaciową"9 , a nie tylko jakością zmysłową. Trudno też zgodzić się ze stwierdzeniem, że przyjemność czy korzyść, a nawet dążenie do szczęścia stanowiłyby ostateczne kryteria ludzkiego postępowania. Sensualistyczny empiryzm skutkuje w konsekwencji subiektywizmem i relatywizmem. W świetle personalizmu etycznego odpowiedzią na akognitywizm, naturalizm i antynaturalizm jest „realistyczne, rozumiejące i intersubiektywnie kontrolowalne doświadczenie osobowej godności człowieka, ujmowanej, z jednej strony na tle całego dostępnego nam empirycznie świata, z drugiej zaś także w kontekście treściowego poznania bytu ludzkiego. U źródeł etycznego personalizmu leży zatem prawda o doświadczalnym poznaniu osobowej godności człowieka" (Krajewski 2011, s. 344) i normatywna moc prawdy o dobru moralnym.

Personalizm etyczny jest więc kognitywizmem i antynaturalizmem. Jest także nową orientacją filozoficzno-etyczną wyrosłą na gruncie chrześcijańskim ${ }^{10}$. A czym w takim razie nie jest? Na to pytanie można odpowiedzieć, przyglądając się współczesnym kierunkom filozoficzno-etycznym, które w większości charakteryzują się utylitaryzmem, subiektywizmem, relatywizmem, sytuacjonizmem oraz dążeniem do eksperymentowania ${ }^{11}$. Zresztą w ponowoczesności etykę normatywną uważa

9 Jest to także uwaga skierowana w stronę antynaturalizmu, który wartość traktuje jako cechę nieempiryczną, odrywając ja od podłoża, bytu i wyprowadzając tym samym porządek aksjologiczny poza racjonalną sprawdzalność. Wartość w takim razie jest jakością postaciową o „pozacechowej” strukturze (Krajewski 2011, s. 345).

10 Nie ma jednej etyki chrześcijańskiej, choć wiodącą jest etyka tomistyczna, na bazie której Karol Wojtyła tworzył etykę normatywnej mocy prawdy (Ślipko 2002, s. 7-13).

11 Ideę etyki eksperymentalnej propaguje m.in. Dietrich Benner. Chociaż posiada ona wiele ciekawych inspiracji, np. idea bycia „moralnie w drodze” oraz idee praktyczne J.F. Herbarta, to w gruncie rzeczy niepokoi swoim eksperymentalnym podejściem do moralności i wychowania moralnego, m.in. poprzez nawoływanie do negocjowania typu moralności właściwego dla danego społeczeństwa i czasu oraz potrzeby nieustannej interpretacji Idei Dobra. W świetle takiej etyki nie ma definitywnej moralności ani definitywnej cnoty, której osoba mogłaby powierzyć swoje myślenie, sądzenie i działanie. To oznacza, że rozstrzygnięcia praktyczne i wybór spośród danych typów moralności zależy tylko i wyłącznie od konkretnej osoby i osądu historii, w której ciągle na nowo toczą się spory o kształt moralności i wciąż na nowo wykracza się poza dokonane już wybory, jakie zostały w nich wyznaczone (Benner 2008, s. 29-60). Trudno jednak zgodzić się z taką logiką i postulatem etyki i moralności. Gdy po drugiej wojnie światowej sądzono w Norymberdze nielicznych zbrodniarzy hitlerowskich, bardzo jasno odwołano się do piątego przykazania Dekalogu, przypominając sobie, że jest ono wyrazem prawa naturalnego i jako swoisty kodeks etyczno-moralny jest większe, tzn. obowiązuje zawsze i wszędzie w stosunku do każdej sytuacyjnej etyki i relatywnej moralności. 
się za zagrożenie dla indywidualnej wolności (Z. Bauman) i z tego powodu nawołuje się do rezygnacji $z$ wielkich teorii etycznych, opierających się na jakichś uniwersalnych i ostatecznych fundamentach (R. Rorty) (Ślipko 2002, s. 14-19, 29-33; Gorczyca 2014, s. 39-43).

\section{Realne i integralne doświadczenie u podstaw etyki normatywnej}

Punktem wyjścia filozofowania Karola Wojtyły i tworzonej przez niego etyki normatywnej mocy prawdy jest integralne doświadczenie człowieka, zarówno zewnętrzne, jak i wewnętrzne, które nie tylko ujawnia bogatą rzeczywistość osoby wraz z jej czynami i przez jej czyny, ale zarazem stwarza podstawy do wyjaśniania i zrozumienia tego, czego się doświadcza. „Bogactwo i różnorodność doświadczenia stanowią jak gdyby prowokację dla umysłu, aby rzeczywistość osoby i czynu raz pojętą starał się jak najwszechstronniej ująć i jak najpełniej wytłumaczyć. To jednakże może się dokonać tylko na drodze coraz głębszego wchodzenia w doświadczenie, w jego zawartość. Dzięki temu osoba i czyn zostają niejako wydobyte z mroku. Coraz pełniej i coraz wszechstronniej się wyłaniają, stając przed poznającym je umysłem" (Wojtyła 200o, s. 64).

U podstaw integralnego doświadczenia człowieka znajduje się doświadczenie etyczne, będące częścią integralną doświadczenia osoby. Doświadczenie to Wojtyła umiejscawia w obszarze współdoświadczania siebie i świata w ich nierozłącznym związku. Jest to doświadczenie rozumiejące - bowiem rozum uczestniczy w bezpośredniości ujęcia przedmiotu, oraz realistyczne - gdyż sięga bytowego wymiaru przedmiotu doświadczenia. Doświadczenie etyczne nie jest natomiast sensualistyczne (to, co jest przedmiotem tego doświadczenia, nie jest ujmowane zmysłowo, choć wywołuje rezonans w zmysłach i uczuciach) i nie ma charakteru apriorycznego $^{12}$.

W związku z powyższymi stwierdzeniami K. Wojtyła pisze, że „doświadczenie moralności zawsze tkwi w doświadczeniu człowieka, a poniekąd nawet jest tym doświadczeniem. Implikacja doświadczeń jest wzajemna i dwustronna. Człowiek przeżywa, a więc i doświadcza siebie samego poprzez moralność, która stanowi szczególną podstawę zrozumienia człowieczeństwa. Z drugiej zaś strony doświadczenia moralności - a w ślad za tym i jej zrozumienia - niepodobna oderwać od człowieka i człowieczeństwa. Zachodzi tutaj związek istotowy. Istota moralności oraz człowieczeństwa są związane z sobą nierozłącznie” (Wojtyła 1969, s. 19).

Doświadczenie etyczne jest syntezą wielu warstw i aspektów. Wyróżnia się w nim dwie fazy: 1) metaprzedmiotową (nazywaną doświadczeniem moralnym), z którą związane są trzy charakterystyczne momenty: poznanie prawdy, w tym szczególnie

12 Oczywiście są różne koncepcje doświadczenia etycznego, które jednak charakteryzują się redukcjonizmem elementów konstytutywnych tego doświadczenia (Krajewski 2006, s. 31-43; Gorczyca 2014, s. 47-70). 
prawdy o dobru; przeżycie normatywnej mocy prawdy i odkrycie moralnej powinności, a także sumienia oraz 2) przedmiotową (nazwaną doświadczeniem moralności) związaną z doświadczaniem przez osobę własnej godności i godności drugiego człowieka oraz ze spełnianiem przez nią czynu moralnie dobrego i poprzez to spełnianiem siebie w czynie moralnie dobrym (Krajewski 2006) ${ }^{13}$.

\section{Doświadczenie jako akt poznania a zagadnienie prawdy}

Doświadczenie świata jest zawsze współdoświadczaniem siebie. Osoba jest zarówno podmiotem, jak i przedmiotem doświadczenia (Wojtyła 20oo). Doświadczenie to wgląd, który wyprzedza wszelki pogląd, światopogląd oraz teorie na temat człowieka i świata. Doświadczenie to akt poznania, dlatego można stwierdzić, że doświadczenie etyczne jest niejako wpisane w akt poznania lub „nabudowane” na tym akcie (Styczeń 2007). Wśród rozmaitych czynności poznawczych, spełnianych przez osobę, szczególną pozycję zajmują akty poznania sądowego, w których to podmiot poznający dokonuje stwierdzenia zachodzenia bądź niezachodzenia przedmiotowych stanów rzeczy. To jest specyficzny moment dla aktów poznania sądowego, który odróżnia je od innych aktów poznania. Jest to asercja dotycząca sądów faktycznie wydanych, a nie tylko pomyślanych. Istotą aktów z asercją jest uświadomienie sobie zgodności aktu poznania z przedmiotem, do którego ten akt się odnosi, czyli stwierdzenie, że „jest tak” bądź „nie jest tak”. To uświadomienie dokonuje się dzięki refleksji in actu exercito (świadomości prerefleksyjnej) - czyli refleksji towarzyszącej aktowi poznania (Krajewski 2007).

$\mathrm{Z}$ momentem asercji pojawiają się obecne w sądzie kategorie prawdy i prawdziwości, rozumiane jako cecha sądu sine qua non ${ }^{14}$. W akcie poznania sądowego przedmiot zostaje ujęty jako zastany, określony i niezależny w swoim istnieniu i własnościach od podmiotu poznającego. Prawda aktu poznania znajduje fundament w prawdzie samej rzeczy, która polega na odsłonięciu się i zamanifestowaniu. Pierwotnie zatem pojęcie prawdy odnosi się bezpośrednio do ujawniającego się bytu. Prawda jest transcendentna ${ }^{15}$ zarówno wobec aktu, jak i w stosunku do

13 W artykule nie dokonuję prezentacji doświadczenia etycznego w ujęciu personalizmu etycznego, gdyż z jego analizą, przeprowadzoną przez omawianą szkołę etyki, zapoznaje nas publikacja Krajewskiego (2006).

14 Według nauki św. Tomasza przedmiotem materialnym rozumu (obiectum materiale) jest byt, natomiast przedmiotem formalnym, właściwym (obiectum formale) jest prawda. Rozum jako władza duchowa człowieka pozwala mu pozostawać w możliwie wszechstronnym kontakcie z rzeczywistością. Rozum posiada zdolność ujmowania prawdy i odróżniania jej od błędu, fałszu oraz kłamstwa. Istotna dla poznawczej relacji rozumu do wszelkiego bytu jest prawdziwość. Aktywność umysłu (rozumu, intelektu) skierowana jest ku prawdzie, która jawi się jako jego własne światło. Można wiec mówić o dynamicznym i twórczym podporządkowaniu rozumu prawdzie (Wojtyła 2000, s. 201-202).

15 Prawda transcendentalna to ontologiczny odpowiednik prawdy bytu (Krajewski 2006, s. 112-113). 
podmiotu tego aktu, co sprawia, że jest podstawą obiektywizmu oraz realizmu aktu poznania (Krajewski 2006, s. 57-58). Podmiot stwierdzając coś w sądzie, zarazem uznaje to, co stwierdza, angażując się tym samym po stronie poznawanej rzeczywistości jako jej świadek i powiernik. Próba zaprzeczeniu prawdy na tym etapie ujawnia heurystycznie, że prawda ma moc normowania podmiotu od początku aktu poznania. Podmiot „widzi”, że zaprzeczając prawdzie, zaprzeczałby samemu sobie. Już w tym momencie prawda odsłania się jako wartość samoistna, wsobna, jawiąc się jako pierwsze dobro człowieka i zarazem pierwsza norma. Stwierdzenie i uznanie prawdy w akcie poznania objawia poprzez autoimperatyw jej normatywną $\operatorname{moc}^{16}$. Uznanie prawdy przez podmiot poznający w asercji sądowej jest więc normotwórcze i jawi się jako actus humanus ${ }^{17}$. Osoba doświadczając w przeżyciu asercji normatywnej mocy prawdy, odkrywa kategoryczny nakaz jej respektowania, czyli powinność moralną. W taki sposób pole moralności związane jest nieodłącznie $\mathrm{z}$ aktem poznania sądowego.

\section{Specyfika i wieloaspektowość doświadczenia etycznego}

Analiza realistycznego i integralnego doświadczenia etycznego dokonywana w ramach etyki normatywnej mocy prawdy wskazuje na różne aspekty doświadczenia osoby, które z kolei kształtują różne, choć komplementarne i nieraz zachodzące na siebie aspekty etycznego personalizmu (Krajewski 2016). Obecnie zostaną one przywołane ze szczególnym zwróceniem uwagi na te elementy, które jawią się jako istotne w procesie kształtowania kultury moralnej.

\section{Doświadczenie zewnętrzne - personalistycznym doświadczeniem powinności afirmacji osobowej godności (aspekt przedmiotowy)}

W kontekście doświadczenia zewnętrznego K. Wojtyła sformułował tzw. normę personalistyczną, która ujmuje osobę na tle świata, na tle różnicy między osobą a rzeczą, gdyż ta pierwsza „różni się od rzeczy strukturą i doskonałością” (Wojtyła 2001, s. 109). Norma ta przybiera dwie formuły: 1) negatywną, stwierdzającą, że osoba jest takim dobrem, którego nie wolno używać, tzn. sprowadzać do roli środka do celu; 2) pozytywną, nawiązującą do chrześcijańskiego przykazania miłości, która stwierdza, że właściwym odniesieniem do każdej osoby jest miłość (Wojtyła 2001). W rozumieniu Wojtyły norma personalistyczna ma dwa sensy:

16 Zagadnienie doświadczenia normatywnej mocy prawdy rozwijał w swojej twórczości ks. Tadeusz Styczeń, który sformułował „werytatywną” koncepcję doświadczenia moralnego, w której prawda jest centralną kategorią etyczną (Styczeń 2013; Krajewski 2016).

17 Czyn, czyli świadome i wolne oraz celowe działanie człowieka, to actus humanus, a zarazem actus personae i actus voluntaries, gdyż będąc działaniem właściwym człowiekowi jako osobie, jest równocześnie źródłem poznania osoby (Wojtyła 2000, s. 73-76, 111-115). 
preetyczny - opisowy i etyczny - normatywny. Dla doświadczenia zewnętrznego, które jest doświadczeniem osoby, ten pierwszy sens jest właściwy. Polega on na tym, że norma personalistyczna wskazuje na samą wartość osoby ${ }^{18}$, na jej wewnętrzną aksjologię, która leży u podstaw porządku moralnego, tzn. moralnego oceniania i normowania. Sens preetyczny omawianej normy jest zarazem uzasadnieniem dla jej etycznego sensu, czyli przykazania (nakazu, powinności) miłości. Norma personalistyczna w warstwie preetycznej urzeczywistnia się wówczas, gdy podmiot przeżywa i traktuje drugiego człowieka jako drugie „Ja” - jako bliźniego. Warunkiem ujęcia drugiego człowieka jako osoby jest doświadczenie osoby własnej.

\section{Doświadczenie wewnętrzne - doświadczeniem rozumnej natury i godności osoby przez nią samą poprzez doświadczanie normatywnej mocy prawdy i spełnianie czynu moralnie dobrego (aspekt podmiotowy)}

$\mathrm{W}$ doświadczeniu wewnętrznym ${ }^{19}$ człowiek jest dany sobie $\mathrm{z}$ jednej strony jako suppositum humanum (podmiotowość metafizyczna), z drugiej zaś jako ludzkie „Ja" (podmiotowość fenomenologiczna - świadomościowa, wyrażająca się przez przeżywanie siebie jako podmiotu). W przeżywaniu osoba sama odsłania się sobie $^{20}$. Informacja o obiektywnym stanie rzeczy doświadczona i przeżyta przez podmiot staje się autoinformacją (Styczeń 2007). Co więc osoba poznaje w akcie poznania sądowego i jaki to ma związek z moralnością?

18 Wartość osoby (jej godność) wynika z jej statusu ontologiczno-aksjologicznego. Człowiek poznając realny świat przedmiotów, doświadcza zarazem, że jest kimś innym i absolutnie nieredukowalnym do tego, co jest i może być przez niego poznawane. To, co różni go od świata rzeczy, tym samym go wyróżnia (per opposita cognoscitur - według średniowiecznej maksymy metodologicznej), sprawiając, że człowiek jest w nim „osobno” i jawi się sam sobie jako ktoś, kto ten świat transcenduje, dzięki czemu jest w nim „inaczej” i „wyżej”. Dla K. Wojtyły transcendencja to drugie imię osoby, ukazuje ona bowiem najpełniej najgłębsze warstwy struktury osoby. Osoba transcenduje naturę poprzez duchowe akty poznania intelektualnego, miłości i wolności oraz akty religijne, objawiając tym samym swoją duchowość (Wojtyła 200o, s. 151-228). Osoba powie św. Tomasz z Akwinu - jest perfectissima in tota natura - najdoskonalszym z bytów na świecie (cyt. za: Krajewski 2016, s. 239-241).

19 Choć Karol Wojtyła sformułował normę personalistyczną w perspektywie doświadczenia zewnętrznego, to analizował przede wszystkim osobę-podmiot daną w doświadczeniu wewnętrznym informującym o jej spełnianiu się poprzez czyn i jego moralną wartość oraz poprzez relacje interpersonalne. Z kolei dla uczniów Wojtyły, szczególnie T. Stycznia i A. Szostka, którzy doprecyzowali koncepcję doświadczenia etycznego, u podstaw zewnętrznego i wewnętrznego doświadczenia znajdują się doświadczenie normatywnej mocy prawdy oraz osobowa godność, która stanowi wprost przedmiot moralnego doświadczenia, stając się źródłem kategorycznej, czyli moralnej powinności.

20 Osoba doświadcza siebie jako suppositum personale (aspekt bytowy) oraz subiectum personale (aspekt świadomościowy), tzn. doświadcza siebie jako podmiot i przeżywa siebie jako podmiot (Wojtyła 2000, s. 73-149). 
Po pierwsze, osoba poznaje prawdę o dobru, w tym prawdę o dobru moralnym ${ }^{21}$. Dobro poznajemy zawsze w perspektywie prawdy, przy czym dobro prawdy wyprzedza prawdę o dobru. Dobrem jest byt, o ile zostanie stwierdzony. Istota transcendentalnego dobra to affirmabile, czyli „domaganie się” respektowania przez byt, który podmiot poznaje. K. Wojtyła podkreśla ów związek prawdy i dobra, które wzajemnie się przenikają. Człowiek dąży do dóbr, ale zawsze kieruje się prawdą o dobru (Wojtyła 2008, s. 193-194, 388-390). W życiu moralnym prawda rozumu broni przed zrelatywizowaniem dobra, zwłaszcza dobra moralnego. Prawda broni też przed sprowadzeniem dobra do uczuć (jak chciał David Hume), do emocji (jak uczył Max Scheler) czy też do czystej formy apriorycznego rozumu praktycznego (jak widział to Immanuel Kant). Prawda o dobru jest zasadą świadomego i wolnego działania osoby. Jest momentem rozszczepienia czynów ludzkich na dobre i złe (Kaczyński 2007, s. 104-105).

Rozum nie tylko ujmuje dobro w świetle prawdy, ale także stwierdza hierarchię pomiędzy dobrami. W ramach doświadczenia prawdy o dobru podmiot poznaje jego trzy rodzaje: bonum honestum (inne „Ja" - osoby), bonum utile (byty pozaosobowe - zwierzęta, rośliny, byty nieożywione) oraz specyficzne dobro - bonum delectabile (piękno). Tylko osoba jest bonum honestum wychodzącym poza utylitarny charakter pozostałych dóbr (Krajewski 2006, s. 97-104). Jest jeszcze szczególny rodzaj dobra, istotnego dla moralności i związanego z osobą, a mianowicie dobro moralne chroniące godność osobową podmiotu. Stanowi ono o właściwym człowiekowi sposobie spełniania się w czynie ${ }^{22}$, a tym samym o jego samostanowieniu $^{23}$, ponieważ osoba spełnia się tylko przez dobro moralne.

21 „Prawda o dobru” jest wyrażeniem często używanym w studiach antropologiczno-etycznych Karola Wojtyły. W wyrażeniu tym nie chodzi o obiektywną prawdę dobra, jaką zna Bóg, ale o prawdę o dobru, jaką poznaje osoba, uwzględniając obiektywność swojej podmiotowości i swoich stosunków z innymi osobami, światem i Bogiem (Wojtyła 20oo, s. 186-187; Kaczyński 2007, s. 88-124).

22 W refleksji filozoficznej K. Wojtyły „spełniać czyn”, nie znaczy tylko być jego sprawcą, ale również spełniać siebie w nim, to znaczy urzeczywistniać, doprowadzać do właściwej pełni strukturę samostanowienia, podkreślającą podstawowy fakt, że człowiek jest kimś, a nie czymś. Od strony ontologicznej każdy czyn jest jakimś spełnieniem osoby. Aksjologicznie jednak owo spełnianie się osoby ludzkiej jest spełnianiem się tylko przez dobro. Przez zło moralne człowiek znajduje się w sytuacji poniekąd „niespełnienia”. Moralność jawi się bowiem jako wewnętrzna właściwość czynów ludzkich. Jest ona związana z czynem rozumianym jako wewnętrzny i nieprzechodni skutek sprawczości, która może mieć dwojaki charakter - przechodni i nieprzechodni. Pierwszy z nich dotyczy kształtowania otaczającej rzeczywistości. Tutaj osoba jest źródłem i przyczyną skutków zewnętrznych istniejących poza nią samą. W drugim przypadku sprawczość wiąże świadome działanie człowieka z własnym podmiotem, stając się samostanowieniem (Wojtyła 200o, s. 194-197).

23 Wolność osoby, dokonująca się przez wolną wolę, utożsamia się z samostanowieniem jako rzeczywistością doświadczalną, najpełniejszą i zarazem najbardziej podstawową. Samostanowienie jest właściwością osoby ujawniającą strukturę samoposiadania, która z kolei jest warunkiem samopanowania. Aby człowiek mógł o sobie stanowić, musi siebie samego posiadać i sobie 
K. Wojtyła ucząc, że tylko rozum może poznać prawdę o dobru, ukazuje istnienie obiektywnych zasad życia moralnego i moralnego działania człowieka. Tym samym przeciwstawia się niebezpiecznej w praktyce koncepcji normotwórczego rozumu, stanowiącej podstawę dla koncepcji normotwórczego sumienia (Wojtyła 2000, s. 180-184; Szostek 1990). Prawda o dobru jawi się jako zasada obiektywna, która pozwala człowiekowi odróżnić w praktyce dobro od zła. Odniesienie do prawdy jest swoistą miarą, kryterium dobra zarówno czynów osoby, jak i samej osoby jako ich podmiotu i sprawcy. Ujęcie samego dobra w świetle prawdy oraz stosunku woli do prawdy o dobru ${ }^{24}$ powinno być rozpatrywane nie tylko na poziomie władz duchowych, jakimi są rozum i wola, ale przede wszystkim w kontekście osoby, która działa przez te władze i w nich. Dlatego zagadnienie prawdy o dobru wiąże się także z kwestią sumienia ${ }^{25}$, powinnością (Wojtyła 200o, s. 206-211), normą moralną i odpowiedzialnością (Wojtyła 20oo, s. 211-216) ${ }^{26}$. Tylko takie ujęcie prawdy o dobru pozwala ukazać ją jako konstytutywny moment moralności (Kaczyński 2007, s. 99-124; Krajewski 2016).

Po drugie, osoba poznaje prawdę o swojej obiektywnej, rozumnej naturze ${ }^{27}$ i związanej z nią godności osobowej ${ }^{28}$, co pozwala m.in. na rozstrzygnięcie, jakie czyny służą prawdziwemu dobru człowieka, a jakie nie ${ }^{29}$. Poznanie natury czło-

samemu panować. Samopanowanie oznacza więc właściwość osoby, dzięki której panuje ona nad własnymi dynamizmami. Samoposiadanie zaś to własność, mocą której osoba decyduje o sobie. Struktury samopanowania i samoposiadania stanowią o człowieku jako osobie, decydują o jego ontologicznej oryginalności oraz stanowią podstawę transcendencji, która jest wyrazem duchowości człowieka (Wojtyła 2000, s. 151-211; Sztaba 2014b).

24 Dojrzały akt wolnej woli zakłada akt poznania. W ujęciu K. Wojtyły źródłowe odkrycie wolności dokonuje się zawsze w horyzoncie poznanej i przeżytej przez podmiot prawdy. Zanim osoba użyje swojej wolności, dana już jej jest kategoryczna powinność respektowania poznanej prawdy. Wolna wola odsłaniając swoją strukturę: „mogę - nie muszę - chcę”, zostaje w sposób konieczny odesłana do „powinienem”, która to powinność jest przekładem normatywnej mocy prawdy na samozobowiązanie (Wojtyła 2000, s. 151-191).

25 Całe zagadnienie spełniania się osoby przez czyn moralnie dobry i poprzez to stawanie się ens morale związane jest z sumieniem. Ono jest władzą, która ujawnia zależność czynów i ludzkiej wolności od prawdy o dobru. Sumienie określa więc prawdziwe dobro w czynie i kształtuje odpowiednią do tego dobra powinność, będącą doświadczalną postacią zależności wolności od prawdy (Wojtyła 2000, s. 198-206; Sztaba 2015).

26 Odpowiedzialność jest ważną kategorią w etyce oraz w wychowaniu moralnym. Świadczą o tym chociażby różne koncepcje etyki odpowiedzialności i fundamentalne zainteresowanie ta wartością w XX wieku (Moń 2016).

${ }^{27} \mathrm{~W}$ dobie ideologii postmodernizmu, dla której wszytko jest tymczasowe i płynne, prawda o niezmiennej ludzkiej naturze jest kontestowana na różny sposób, co rodzi wiele trudności i kryzysów, np. zagadnienie gender (Maryniarczyk i in. 2014).

28 Godność osobowa jest centralną wartością w personalizmie etycznym, a zarazem pojęciem trudnym do zoperacjonalizowania (Sztaba 2013b).

${ }^{29}$ Czyn jest moralnie dobry, gdy uznaje dobro, jakim jest osoba; jest moralnie zły, gdy to dobro narusza. 
wieka jest więc absolutnie koniecznym warunkiem określenia szczegółowej treści aktów afirmacji należnej osobie, ponieważ natura ludzka dzięki osobowej godności jej nosiciela ma charakter normatywny, tzn. wyznacza słuszność postępowania, pozwalając na uchwycenie specyfiki moralnego dobra, które polega na adekwatnej w stosunku do osoby odpowiedzi, respektującej doświadczalnie dany ontologiczno-aksjologiczny status osoby ${ }^{30}$. Natura jawi się więc jako obiektywny i racjonalny drogowskaz ludzkiego działania. Bez jej poznania nie jest możliwe efektywne działanie na rzecz dobra osoby ${ }^{31}$. Natura i wpisane w nią inklinacje wyznaczają obiektywny porządek dóbr (ordo bonorum), stanowiący podstawę prawdziwości norm moralnych (ordo caritatis) ${ }^{32}$. Wyznaczony przez naturę ludzką obiektywny porządek dobra jest jedynym źródłem absolutnego charakteru norm moralnych. Konsekwencją negowania stałej natury są modny dziś relatywizm i sytuacjonizm norm moralnych.

\section{Doświadczenie międzyosobowe - doświadczeniem uczestnictwa i osobowego bycia darem (aspekt komunijny)}

Ponieważ osoba ludzka jest bytem przygodnym, potencjalnym i niesamowystarczalnym, dlatego $\mathrm{z}$ natury jest bytem otwartym na drugą osobę oraz wspólnotę. Od strony negatywnej potwierdza to doświadczenie samotności (Sztaba 2013a). Natomiast dynamizm i charakter tego otwarcia uwidacznia się i częściowo wyjaśnia poprzez wewnętrzny rys osoby nazwany komunijnością ${ }^{33}$, wyrażający się poprzez uczestnictwo, transcendencję oraz aspekt daru.

30 Takie ujęcie relacji osoby i natury pozwala na uniknięcie błędu zarówno naturalizmu, który redukuje osobę do natury, jak i antynaturalizmu, odrywającego osobę od natury (Krajewski 2011, s. 351).

31 Na potrzebę odczytania natury ludzkiej jako zadanej do afirmacji wskazuje prawo naturalne i związane z nim inklinacje (naturalne skłonności, o których uczyła już klasyczna etyka), odsyłające do pewnych dóbr, bez których respektowania nie ma prawdziwej afirmacji osoby. Zalicza się do nich: 1) inklinację do zachowania życia, wskazującą na wartość życia; 2) inklinację do przekazywania życia, wskazującą na miłość jako szczególne dobro i 3) inklinację do integralnego osobowego rozwoju przez rozumną wolność, dokonującą się w prawdzie, dobru i miłości (Krajewski 2011, s. 351).

${ }^{32}$ Należy w tym kontekście pamiętać o tym, że norma jest zawsze wtórna wobec dobra.

33 Zdaniem K. Wojtyły, komunijność ujawnia szczególną prawidłowość bytowania osobowego, które jest bytowaniem „z kimś” i „dla kogoś”. Komunia osób oznacza bytowanie we wzajemnym „dla”, tzn. w relacji wzajemnego daru, która wypełnienia pierwotną samotność człowieka. W osobie ludzkiej kryje się nie tylko zdolność bycia darem, ale również zdolność i zarazem głęboka gotowość afirmacji drugiej osoby. Jest ona niczym innym jak podjęciem daru, które poprzez wzajemność stwarza komunię osób. 
Uczestnictwo $^{34}$ jest wewnętrzną i dynamiczną właściwością osoby. K. Wojtyła opisuje dwa jego podstawowe znaczenia (Wojtyła 20oo, s. 447-461). Pierwsze związane jest $z$ uczestnictwem w samym człowieczeństwie drugiej osoby, poprzez pozostawanie z nią w żywej relacji. Na to uczestnictwo wskazuje słowo „bliźni”. Drugie znaczenie uczestnictwa związane jest ze spełnianiem siebie jako osoby we współżyciu i współdziałaniu z innymi na rzecz dobra wspólnego (Wojtyła 2000, s. 402-409; Sztaba 2016). Uczestnictwo swoją pełnię osiąga w „darowości” osoby, tzn. w zdolności bycia bezinteresownym darem $\mathrm{z}$ samego siebie dla innych (Wojtyła 2000, s. 430-431; Krajewski 2016, s. 250-256). Zdaniem Wojtyły jest to istotny rys osobowego istnienia i działania człowieka. Tej właściwości nie sposób zrozumieć bez wniknięcia w sam byt i dobro, jakie każda osoba stanowi w swojej istocie. Metafizycznymi warunkami możliwości bycia bezinteresownym darem ${ }^{35}$ przez osobę są struktury samoposiadania i samoopanowania ${ }^{36}$. Tylko ten, kto jest własnością samego siebie, może też siebie samego oddać. I podobnie tylko ten, kto jest panem samego siebie, może uczynić siebie darem dla innych. Dar z siebie nie narusza metafizycznego charakteru samej osoby, wyrażonej łacińskim adagium: Persona est alteri incommunicabilis. Owo oddanie dokonuje się bowiem na płaszczyźnie decyzji i wyboru - a więc ma charakter moralny, a nie metafizyczny. Osoba jest nieprzekazywalna metafizycznie, ale jest „przekazywalna” moralnie.

Uczestnictwo tworzy wspólnotę, która nie jest matematyczną wielością podmiotów, ale wielością i różnorodnością relacji (Wojtyła 1974). Communio personarum to międzyosobowy układ zbudowany na godności osób i nastawiony na ich afirmację poprzez respekt dla normy personalistycznej. Doświadczenie relacji do drugiej osoby pozwala człowiekowi w nowy sposób przeżyć własną podmiotowość poprzez otwarcie się na perspektywę miłości. Bez drugiego „Ja” osoba pozostaje samotna, natomiast relacja "Ja” - „Ty” mocniej osadza ją w jej własnej podmiotowości, potwierdzając ją i umacniając (Wojtyła 2000, s. 408; Krajewski 2016, s. 254-255). Przeciwieństwem tak rozumianego uczestnictwa jest alienacja odbierająca (ograniczająca lub uniemożliwiająca) człowiekowi jako osobie możliwość spełnienia siebie na gruncie bytowania i działania „wspólnie z innymi” (Wojtyła 2000).

34 Kategoria uczestnictwa ma w nauczaniu K. Wojtyły (ale nie tylko) wartość hermeneutyczną, tzn. wyjaśniającą i rozumiejącą. Dzięki niej łatwiej zrozumieć komunijność osoby ludzkiej i wspólnotę osób jako communio personarum, wyrażającą się poprzez transcendencję i bycie bezinteresownym darem jednej osoby dla innych (Sztaba 2011).

35 Bezinteresowność jest podstawową cecha daru, która wskazuje na ponadutylitarny charakter samej osoby (Olbrycht 2015).

36 Zob. powyżej, przypis 23. 


\section{Doświadczenie przygodności osoby i jej ostatecznej przyczyny (aspekt teistyczny)}

Nie bez wpływu na moralność pozostaje metafizyczne doświadczenie przez osobę poznającą jej własnej przygodności, czyli niekonieczności istnienia. Z metafizyczną przygodnością wiąże się także przygodność etyczna, polegająca na konieczności ciągłego wyboru i nieusuwalnego znajdowania się w „matni” dobra i zła (Wojtyła 2000, s. 198). Osoba jest skazana na wybór między dobrem i złem, gdyż rezygnacja z tego także jest wyborem. Próba wyjścia poza dobro i zło jest autoiluzją. W kontekście przygodności metafizycznej bardzo ważne jest dostrzeżenie faktu, że byt, który nie istnieje sam z siebie, domaga się w imię zasady racji ostatecznej, proporcjonalnej przyczyny dla swojego istnienia. W przypadku człowieka jest to Absolut Istnienia i Miłości - Bóg (Krajewski 2016, s. 256-257). Przygodność nie niszczy godności osobowej, lecz odsłania jej ostateczne źródło. Poznanie metafizyczne pozwala więc odkryć Stwórcę człowieka, o którym pisał św. Ireneusz z Lyonu, że gloria Dei homo vivens (chwałą Boga jest człowiek żyjący). Osoba jawi się jako teofania, tzn. miejsce objawiania się osobowego Absolutu. W taki sposób Bóg, jako ostateczna racja istnienia osoby, jawi się zarazem jako ostateczna racja porządku moralnego. Oznacza to w konsekwencji, że akt moralny nie tracąc swojej autonomii, okazuje się implicite aktem religijnym. Odnosząc się bezpośrednio (explicite) do człowieka, pośrednio (implicite) odnosimy się do jego Stwórcy. Metafizyka pozwala odkryć ostateczne korzenie godności człowieka i zarazem Autora porządku moralnego, który (to porządek) ze swojej istoty jest otwarty na religię ${ }^{37}$.

\section{Doświadczenie winy/grzechu (aspekt chrystologiczny)}

Po umysłowym poznaniu prawdy o dobru oraz po intencjonalnym akcie chcenia, sprzęgniętym z momentami rozstrzygnięcia i wyboru ${ }^{38}$, następuje moment przejścia od prawdy o dobru do urzeczywistniania tego dobra w czynie, a poprzez niego akt spełniania się osoby. Jest to moment właściwy w doświadczeniu moralności. Bowiem moralność to nie realizacja spontanicznych chceń woli, ale koordynacja woli z prawdą rozumu o dobru ${ }^{39}$. Człowiek spełnia się przez realizację czynu

${ }^{37}$ Zagadnienie to omawiają różni filozofowie etycy w drugiej części publikacji: S. Janeczek, A. Starościc (2016).

${ }^{38}$ Zob. powyżej, przypis nr 24.

${ }^{39}$ Moralność jest doskonałością woli, z którą jest ściśle związana. Istoty obdarzone właściwością poznawczą mogą ujmować prawdę, dociekać jej i do niej dążyć. Istoty obdarzone rozumną wolą mogą i powinny realizować dobro moralne. „Osobie ludzkiej - napisze K. Wojtyła - przysługuje wolność nie jako czysta niezależność, ale jako samozależność, w której zawiera się zależność od prawdy. Ona to stanowi nade wszystko o duchowym dynamizmie osoby. Ona też równocześnie wskazuje dynamikę spełniania się osoby, jak i jej niespełnianie się w znaczeniu etycznym [...]. Zależność od tej prawdy konstytuuje osobę w jej transcendencji; transcendencja wolności 
moralnie dobrego, gdy jest wierny poznanej i uznanej prawdzie o dobru moralnym. Natomiast się nie spełnia, gdy sprzeniewierza się poznanej prawdzie, realizując czyn moralnie zły. Nie jest to jednak błąd, ale wina moralna prowadząca do autodestrukcji, samounicestwienia moralnego, tragizmu moralnego ${ }^{40}$. Człowiek odrzucając poznaną przez siebie prawdę $\mathrm{w}$ akcie wolnego wyboru, odrzuca wówczas samego siebie, jako jej świadka i powiernika. Wybór sprzeczny z prawdą jest „uderzeniem” we własną osobową podmiotowość, która polega na wolności w prawdzie, czyli na autotranscendencji. Gdy osoba aktem wyboru przeczy aktowi poznania, wówczas narusza swoją tożsamość, wprowadzając „nie-Ja” w swoje "Ja”"41. Człowiek czyniąc zło moralne, staje się złym człowiekiem, czyli takim, jakim nie powinien być. Dramat winy polega na tym, że człowiek nie jest w stanie sam się z niego wyzwolić. Wina bowiem nie jest tylko złem moralnym, ale jest także grzechem z powodu sprzeniewierzenia się Stwórcy, który jest Prawdomówny. Etyka stając wobec problemu winy, stwierdza, że jest on nierozwiązywalny przez nią i wskazuje na teologię moralną, która uczy, że tylko Bóg może oczyścić z winy, a to jest co innego niż przebaczenie (Krajewski 2016, s. 257-260). Odpowiedzią na dramat winy jest chrześcijańska kerygma, którą niesie Objawienie o Bogu Człowieku - Jezusie Chrystusie jedynym Odkupicielu człowieka (Styczeń 2007, s. 92-99).

\section{Specyfika i oryginalność etyki normatywnej mocy prawd a problem kształtowania kultury moralnej młodego pokolenia - spostrzeżenia i postulaty}

Etyka normatywnej mocy prawdy Karola Wojtyły i jego uczniów zrodziła się jako owoc wglądu podmiotu w samego siebie, przy okazji spełniania aktu poznania świata ${ }^{42}$. Jej punktem wyjścia jest doświadczenie i przeżycie normatywnej mocy prawdy, a nie naturalne pragnienia człowieka. Zbudowana na integralnym doświadczeniu jest etyką normatywną; teorią opisującą, interpretującą i wyjaśniającą moralną powinność działania. Integralne doświadczenie jest także gwarancją realizmu i obiektywizmu oraz racjonalności i intersubiektywnej sprawdzalności prezentowanego doświadczenia moralnego (Krajewski 2007). Wracając do

przechodzi w transcendencje moralności” (Wojtyła 200o, s. 198). Tylko voluntas recta (prawa wola), tj. wola kierująca się prawdą, jest w stanie prowadzić człowieka ku prawdziwemu dobru.

40 Jean Paul Sartre taką sytuację nazwał w swoim dramacie Przy drzwiach zamkniętych (1944) piekłem, nie widząc wyjścia z tej sytuacji. Ale ono jest, tylko poza etyką. Niesie ją w sposób szczególny teologia katolicka, ze swoją nauką o Bożej łasce i odpuszczeniu grzechów oraz darowaniu win (Krajewski 2016, s. 258).

41 Ks. Tadeusz Styczeń nazywa tę sytuację „sprawą Owidiusza”, przywołując znane jego powiedzenie: Video meliora proboque deteriora sequor - „widzę i pochwalam to, co lepsze, lecz wybieram gorsze" (Krajewski 2016, s. 257).

42 Poznanie etyczne mieści się w ramach normalnego uposażenia aparatu poznawczego osoby (Krajewski 2006, s. 151-152). 
współczesnego sporu o etykę i moralność, poruszonego w pierwszym punkcie artykułu, z całą stanowczością można stwierdzić, że etyka normatywnej mocy prawdy jest kognitywizmem ${ }^{43}$ i antynaturalizmem (Krajewski 2011, s. 355$)^{44}$.

Etyka normatywnej mocy prawdy opierając się na własnym doświadczeniu, jest nauką autonomiczną, czyli epistemologicznie i metodologicznie niezależną od innej dziedziny poznania. Dzięki swojej specyfice związanej z punktem wyjścia (normatywna moc prawdy) jawi się jako philosophia prima ${ }^{45}$. Antropologia, metafizyka, teoria poznania i inne nauki konstytuują się bowiem zawsze w i przez doświadczenie etyczne. Dzieje się tak, ponieważ normatywność poznania i odpowiedzialność podmiotu za prawdę to warunki etyczne każdego naukowego poznania. Ale jest i niejako druga strona medalu - prezentowana etyka jest w stanie realnie i adekwatnie odpowiedzieć na podstawowe etykotwórcze pytanie - co i dlaczego powinienem?, ponieważ ściśle współpracuje z teorią poznania, antropologią i metafizyką (Krajewski 2006, s. 16-20). Normatywna moc prawdy sprawia, że primum ethicum et primum anthropologicum et primum metaphysicum er primum gnoseologicum convertuntur (Krajewski 2007, s. 186).

Etyka normatywnej mocy prawdy jawi się także jako philosophia ultima - nauka, która określa warunki ostatecznego spełniania się osoby przez dobro moralne. Wskazując natomiast na problem winy moralnej, który nie może być rozwiązany na swoim gruncie, prezentowana etyka otwiera się na teologię, „słuchając” wieści o wybawieniu ze zła moralnego. Na gruncie więc doświadczenia winy, ale także przygodności człowieka i normy personalistycznej etyka otwiera się na teologię, stając się preambulum fidei ${ }^{46}$. Etyka normatywnej mocy prawdy jest świadoma faktu, że będąc otwarta na Objawienie, jest zdolna trafnie odsłonić i adekwatnie wyjaśnić daną powinność moralną $a^{47}$.

${ }^{43}$ Kognitywizm opiera się na czterech filarach: 1) poznaniu natury ludzkiej (prawo naturalne); 2) doświadczeniu osobowej godności (norma personalistyczna); 3) sumieniu (racjonalnie uzasadniony sąd sumienia) i 4) Absolucie (ostateczna racja moralności).

${ }^{44}$ Antynaturalizm personalizmu etycznego polega na przeświadczeniu, że osobowa godność jako podstawowa kategoria moralnotwórcza nie jest wyprowadzona z natury ludzkiej, ale może być zobaczona w doświadczeniu, które jest nieodłącznie związane z „treściowym” poznaniem człowieka.

${ }^{45}$ Tezę tę sformułowaną przez K. Krajewskiego podzielają także m.in. ks. T. Styczeń (jego mistrz) oraz ks. ks. A. Szostek i W. Stróżewski - recenzenci pracy doktorskiej wspominanego autora, w której tezę tę zawarł i uzasadnił.

${ }^{46}$ O konieczności otwarcia się etyki na Objawienie pisał chociażby J. Maritain, twierdząc, że tylko teologia dysponuje pełną wiedzą na temat sytuacji moralnej człowieka (grzech pierworodny, wina moralna) i środkami prowadzącymi do jego wyzwolenia (Krajewski 2006, s. 21-22, 155-161).

${ }^{47}$ Jan Paweł II podczas swojego nauczania wielokrotnie przypominał, że zrąb moralności został dany człowiekowi przez Stwórcę, Najwyższego Prawodawcę, który wpisał „w serce człowieka cały porządek prawdy. Porządek ten warunkuje dobro i ład moralny i przez to jest podstawa godności człowieka stworzonego na obraz Boży. Przykazania zostały dane dla dobra człowieka, jego dobra osobistego, rodzinnego i społecznego. One są naprawdę drogą dla człowieka. Sam 
Zaprezentowana etyka, z jej kluczowymi elementami, na które wskazują różne aspekty doświadczenia etycznego, jawi się jako adekwatna teoria moralności, zdolna kształtować moralno-etyczne kompetencje w ramach systemu oświaty w nowoczesnym społeczeństwie w celu szerzenia autentycznej kultury moralnej młodego pokolenia (choć nie tylko). Przy czym proces kształtowania powinien być rozumiany po Herbartowsku - jako nauczanie wychowujące, które nie jest już tylko prostym przekazem wiedzy zdążającym do zmiany wyznawanych norm moralnych, ale także wychowaniem moralnym nauczającym, dotyczącym sposobów zmiany moralnej jakości czynów ludzkich (Piskurewicz, Stępkowski 2006).

Etyka normatywnej mocy prawdy dzięki temu, że jest realistyczna, racjonalna, obiektywna i uniwersalistyczna, gdyż opiera się w swoich analizach na realnym oraz integralnym doświadczeniu, może wspierać ten proces, ponieważ:

1) wyraźnie uzasadnia tezę, że moralność jest czymś do odkrycia, „zobaczenia” i przeżycia, bo jest sprawą doświadczenia oraz rozumnego (prawdziwościowego) i wolnego wyboru osoby. Wskazuje tym samym na nierozłączny związek moralności i osoby ${ }^{48}$;

2) wbrew postmodernistycznej tendencji do relatywizacji wszystkiego przypomina prawdę o racjonalnej naturze człowieka i jego osobowej godności, które wyznaczają obiektywny porządek dobra, będący jedynym źródłem absolutnego charakteru norm moralnych;

3) przywraca (uzasadniając to w oparciu o doświadczenie) należne miejsce rozumowi i jego zdolności do odkrywania prawdy, demaskując tym samym takie stanowiska, jak sceptycyzm, agnostycyzm oraz relatywizm (Sochoń 2011);

4) uzasadnia istnienie i sens takich wartości, jak: prawda, dobro (dobro i zło moralne), odpowiedzialność, wolność (samostanowienie), uczestnictwo, sumienie dla rozwoju autentycznej moralności;

5) bardzo wyraźnie wskazuje na istotę wartości moralnej czynu osoby, która polega na odniesieniu go do prawdy o dobru, normy moralnej. Na tym też polega samospełnianie się i autotranscendencja człowieka, który „musi stale [...] niejako przekraczać siebie w kierunku dobra prawdziwego: jest to podstawowy kierunek owej transcendencji, która stanowi właściwość osoby ludzkiej proprium personae" (Wojtyła 2000, s. 389);

porządek materialny nie wystarczy. Musi być uzupełniony i ubogacony przez porządek nadprzyrodzony. Dzięki niemu życie nabiera nowego sensu, a człowiek staje się doskonalszy. Życie bowiem potrzebuje mocy i wartości Bożych, nadprzyrodzonych, wtedy dopiero nabiera pełnego blasku" (Jan Paweł II, Homilia w czasie nabożeństwa czerwcowego, Elbląg, o6.06.1999).

${ }^{48}$ Moralność - napisze K. Wojtyła - jawi się „nie jako abstrakt, ale jako najściślejsza egzystencjalna rzeczywistość związana z osobą jako właściwym sobie podmiotem" (Wojtyła 200o, s. 147, 293; Sztaba 2014a). 
6) odwołując się do społecznej natury człowieka (komunijność, uczestnictwo, „darowość"), przypomina o społecznym wymiarze moralności i ważności relacji dla autokonstytucji i autoteleologii ${ }^{49}$ osoby;

7) wskazuje na potrzebę współpracy rozumu, wolnej woli i uczuć w urzeczywistnianiu czynu moralnie dobrego oraz ich permanentnej formacji w ramach pracy nad charakterem w celu integracji osoby w czynie (Wojtyła 20oo; Piątkowska, Stępień 2005);

8) zajmując stanowisko wobec stawianej dziś pozornej alternatywy: religia czy etyka, wyraźnie stwierdza, że jeśli Bóg jest racją ostateczną istnienia człowieka (przygodność osoby) i racją ostateczną moralności (Bóg jest Najwyższym Dobrem i On rozwiązuje problem winy moralnej $)^{50}$, to kształcenie/wychowanie etyczno-moralne powinno być otwarte na dane Objawienia, teologię i wychowanie religijne (chrześcijańskie) (Boużyk 2013, s. 234-248; Horowski 2015, s. 337-344, 375-381).

Etyka normatywnej mocy prawdy wskazuje na nierozłączny związek moralności i osoby. Prawda jest pierwszą normą, jaką podmiot poznający odkrywa i zarazem podstawową zasadą wychowania (Starnawski 2008). Doświadczenie normatywnej mocy prawdy umożliwia osobie poznającej percepcję osobowej godności swojej i drugiego. Doświadczenie aktu poznania i normatywnej mocy prawdy kulminuje się w doświadczeniu miłowania osoby (norma personalistyczna).

\section{Bibliografia}

Benner D. (2008). Edukacja jako kształcenie i kształtowanie. Moralność - kultura demokracja - religia, tłum. D. Stępkowski. Warszawa: Wydawnictwo UKSW, s. $29-60$.

Boużyk M.M. (2013). Wychowanie otwarte na religię. Polska Szkoła Filozofii Klasycznej o roli religii w wychowaniu. Warszawa: Wydawnictwo UKSW.

Gorczyca J. (2014). Zarys etyki fundamentalnej. Kraków: Wydawnictwo WAM.

Horowski J. (2015). Wychowanie moralne według pedagogiki neotomistycznej. Toruń: WN UMK.

Jan Paweł II (1988). W imię przyszłości kultury. Przemówienie w siedzibie ONZ do Spraw Oświaty, Nauki i Kultury (UNESCO), Paryż, o2.06.198o. W: M. Radwan, S. Wylężek, T. Gorzkula (red.). Jan Paweł II. Wiara i kultura. Dokumenty, przemówienia, homilie. Rzym-Lublin: RW KUL, s. 51-68.

49 Autoteleologia człowieka polega na samostanowieniu i spełnianiu siebie w czynie moralnie dobrym, co prowadzi równocześnie do zgodności z samym sobą i z prawdą o dobru (Wojtyła 2000, s. 480-487).

50 Maksyma Fiodora Dostojewskiego: „jeśli Boga nie ma, wszystko jest dozwolone”, zawarta w powieści Bracia Karamazow, bardzo dobitnie wskazuje na potrzebę teistycznej etyki normatywnej, uwydatniając zarazem słabość m.in. etyki I. Kanta czy etyki niezależnej T. Kotarbińskiego, nie mówiąc już o różnych odmianach etyki sytuacyjnej, np. P. Singera (Wojtysiak 2007, s. 155-178). 
Kaczyński E. (2007). Prawda - dobro - sumienie. Z zagadnień teologii moralnej. Warszawa: Pax.

Krajewski K. (2006). Etyka jako filozofia pierwsza. Doświadczenie normatywnej mocy prawdy źródłem i podstawa etyki. Lublin: Wydawnictwo KUL.

Krajewski K. (2007). Od Karola Wojtyły „normatywnej mocy prawdy” do idei etyki jako antropologii normatywnej i filozofii pierwszej. W: K. Krajewski (red.). Racjonalność $w$ etyce. Normatywna moc prawdy. Lublin: Wydawnictwo KUL, s. $167-187$.

Krajewski K. (2010). Emocjonalizm w życiu moralnym. W: A. Maryniarczyk, K. Stepień, P. Gondek (red.). Osoba i uczucia. Lublin: Polskie Towarzystwo Tomasza z Akwinu, s. 429-435.

Krajewski K. (2011). Racjonalność etycznego personalizmu. W: A. Maryniarczyk, K. Stepień, P. Gondek (red.). Spór o prawdę. Lublin: Polskie Towarzystwo Tomasza z Akwinu, s. 339-356.

Krajewski K. (2016). Personalizm etyczny $w$ lubelskiej szkole filozoficznej. W: S. Janeczek, A. Starościc (red.). Etyka. Koncepcje etyki, część I. Lublin: Wydawnictwo KUL, s. 229-261.

Maryniarczyk A., Stępień K., Gudaniec A. (red.) (2014). Spór o naturę ludzką. Lublin: Polskie Towarzystwo Tomasza z Akwinu.

Moń R. (2016). Etyki odpowiedzialności. W: S. Janeczek, A. Starościc (red.). Etyka. Koncepcje etyki, część I. Lublin: Wydawnictwo KUL, s. 17-211.

Olbrycht K. (2015). Rola bezinteresowności w rodzinie. W: A. Rynio, K. Braun, ks. M. Jeziorański, I. Szewczak (red.). Obudzić (nie)odkryty potencjał małżeństwa i rodziny. Lublin: Wydawnictwo Episteme, s. 39-51.

Piątkowska A., Stępień K. (2005) (red.). Wychować charakter. Lublin: Wydawnictwo Gaudium.

Piskurewicz J., Stępkowski D. (2006). Herbart znany i nieznany. W dwusetna rocznice wydania Pedagogiki ogólnej. Warszawa: Wydawnictwo Salezjańskie.

Rodziński A. (2011). U podstaw kultury moralnej, Lublin: Wydawnictwo KUL.

Sochoń J. (2011). Usytuowanie prawdy w projekcie postmodernistycznym. W: A. Maryniarczyk, K. Stępień, P. Gondek (red.). Spór o prawdę. Lublin: Polskie Towarzystwo Tomasza z Akwinu, s. 223-234.

Starnawski W. (2008). Prawda jako zasada wychowania. Podstawy pedagogii personalistycznej w nawiązaniu do myśli Karola Wojtyły- Jana Pawła II. Warszawa: Wydawnictwo UKSW.

Styczeń T. (2007). Normatywna moc prawdy, czyli być soba to przekraczać siebie ( $w$ nawiazaniu do Karola Wojtyly etyki jako antropologii normatywnej). W: K. Krajewski (red.). Racjonalność w etyce. Normatywna moc prawdy. Lublin: Wydawnictwo KUL, s. 78-87.

Styczeń T. (2013). Etyka jako antropologia normatywna. W: K. Krajewski (red.). Wolność w Prawdzie. Lublin: TN KUL i Instytut Jana Pawła II KUL. 
Styczeń T. (2016). Kardynał Wojtyła - filozof moralista. W: S. Janeczek, A. Starościc (red.). Etyka. Koncepcje etyki, część I. red. Lublin: Wydawnictwo KUL, s. 381-393.

Szostek A. (1990). Natura, rozum, wolność. Filozoficzna analiza koncepcji twórczego rozumu we współczesnej teologii moralnej. Rzym: Fundacja Jana Pawła II.

Sztaba M. (2011). Kategoria uczestnictwa w odniesieniu do rodziny w świetle myśli Karola Wojtyły-bł. Jana Pawła II, „Nauki o edukacji”, nr 6, s. 39-52.

Sztaba M. (2013). Pedagogika integracyjna wobec wieloaspektowego problemu samotności człowieka. „Rozprawy Społeczne”, nr 1, s. 52-6o.

Sztaba M. (2013b), W poszukiwaniu adekwatnego i integralnego rozumienia godności człowieka. Metodologiczne problemy i pedagogiczne implikacje. „Studia Pedagogiczne. Problemy społeczne, edukacyjne i artystyczne”, nr 22, s. 83-10o.

Sztaba M. (2014a). Człowiek jako byt moralny w myśli Karola Wojtyły - Jana Pawła II. W: A. Różyło, M. Sztaba (red.). Człowiek w refleksji Karola Wojtyły Jana Pawła II. Wybrane aspekty adekwatnej antropologii. Lublin: Wydawnictwo KUL, s. 115-137.

Sztaba M. (2014b). Kwestia wolności osoby w myśli Karola Wojtyły - Jana Pawła II. Implikacje pedagogiczne. W: S. Sztobryn, K. Kamiński (red.). Wolność a wychowanie. Problemy, dylematy, kontrowersje, seria „Rzeczywistość edukacyjna”. T. 2. Łódź: WN WSP, s. 149-173.

Sztaba M. (2015). Pedagogiczne implikacje analizy faktu sumienia. W: R. Ceglarek, M. Sztaba (red.). Być człowiekiem sumienia. Interdyscyplinarny namysł nad fenomenem sumienia. Częstochowa: Wydawnictwo Archidiecezjalne Regina Poloniae, s. 95-138.

Sztaba M. (2016). Dobro wspólne jako podstawowa wartość społeczna i zasada życia społecznego. Refleksje pedagoga społecznego. W: S. Sztobryn, K. Kamiński (red.). Centralne kategorie współczesnej i historycznej pedagogiki, seria „Rzeczywistość edukacyjna”. T. 3. Łódź: WN TPF „CHOWANNA” [w druku].

Ślipko T. (2002). Zarys etyki ogólnej. Kraków: Wydawnictwo WAM.

Wiśniewski R. (2016). Wartość absolutna a problemy moralnej praxis. W: S. Janeczek, A. Starościc (red.). Etyka. Filozoficzna etyka życia spetnionego, część II. Lublin: Wydawnictwo KUL 2016, s. 600-612.

Wojtyła K. (1074). Rodzina jako „communio personarum”. „Ateneum Kapłańskie”. T. 83, s. 347-361.

Wojtyła K. (1969). Problem doświadczenia w etyce. „Roczniki Filozoficzne”, nr 17, Z. 2, s. $15-27$.

Wojtyła K. (200o). Osoba i czyn oraz inne studia antropologiczne, wyd. 3. Lublin: TN KUL.

Wojtyła K. (2001). Miłość i odpowiedzialność. Lublin: TN KUL.

Wojtyła K. (2008). Wykłady lubelskie. Warszawa: KAI.

Wojtysiak J. (2007). Filozofia i życie. Kraków: Wydawnictwo Znak. 


\title{
THE IMPORTANCE OF NORMATIVE ETHICS FOR SHAPING THE MORAL CULTURE OF YOUNG GENERATIONS. THE REFLECTION IN THE LIGHT OF KAROL WOJTYŁA'S TEACHING - JOHN PAUL II AND HIS STUDENTS
}

\begin{abstract}
John Paul II reminded in the UNESCO headquarters in Paris on 2nd June 1980 that moral culture is the first and basic dimension of each authentic culture which is "the right shape of man's life itself." A young person should acquire the moral culture inter alia in the way of education i.e. instruction and upbringing. An ethical reflection on life and a person's activity is an important element in this thesis. However, not every ethics (ethical model, ethical direction) favours the mentioned process. The suggested article presents the main ideas of the normative ethics in reference to the moral culture in the theological and philosophical thought of Karol Wojtyła - St. John Paul II.
\end{abstract}

Keywords: normative ethics, moral culture, morality, truth, moral good and evil, conscience.

Mariusz Sztaba - ksiądz katolicki, doktor pedagogiki, licencjat kanoniczny z teologii dogmatycznej. Obszary zainteresowań badawczych: pedagogika społeczna, pedagogika ogólna, pedagogika chrześcijańska i katolicka nauka społeczna. Publikacje książkowe: Tolerancja, ale jaka? Koncepcja wychowania do tolerancji w świetle nauczania Jana Pawła II do Polaków (2006), Troska bł. Jana Pawła II o etyczno-moralne podstawy życia społecznego (2011), Wychowanie społeczne w świetle nauczania Karola Wojtyły - Jana Pawła II (2012), Benedykt XVI. „Aby na nowo odkryć radość w wierze...”. Antologia papieskich wypowiedzi na tematwiary,watpienia i ateizmu (2014). Adres majlowy: sztabowy@gmail.com. 